\title{
Bibliography
}

\section{Archive collections}

\section{Birmingham City Library}

National Council of Women, 1928-1931, Birmingham Branch Archive. MSS 841 B

\section{Lambeth Palace Library, London}

Letters and Papers of G. F. Fisher, Archbishop of Canterbury 1945-61. Vols. 17, 105, 190, 249, 250, 265

Letters and Papers of C. G. Lang, Archbishop of Canterbury, 1928-42. Vols. 107, $113,136,152,178$

Letters and Papers of William Temple, Archbishop of Canterbury, 1942-44. Vol. 35 Mothers' Union Archive MU/

\section{London Metropolitan Archive}

National Council of Women Archive ACC/3613/

\section{Mary Sumner House, London}

Mothers' Union Archive (accessed 1992-95, now catalogued and located in Lambeth Palace Library)

Annual Reports of the Mothers' Union London Diocese, 1928-50

Executive Committee Minutes Vol. 12, 1937

Minute Book of the Mothers' Union, Holy Cross St. Pancras Branch, 1931-40

Minutes of the Mothers' Union Central Council, Vols. 8-12 (1927-50)

Mothers' Union London Diocese Press Cutting Collection, 1889-1934

Mothers' Union Pamphlet Collection

\section{Modern Records Centre, University of Warwick}

Trades Union Congress National Archive (Correspondence with women's organisations) MSS 292/821

YWCA National Archive MSS 243/

\section{Public Record Office, London}

Memorandum of the Women's Housing Conference (n.d., circa 1936), HLG 36/3

\section{Women's Library, London}

Equal Pay Campaign Committee Archive MSS 6CCS/

National Federation of Women's Institute Archive MSS 5/FWI/

National Union of Societies for Equal Citizenship Archive MSS 7AMP/D/2/3

National Women Citizens' Association Archive MSS 5 NWC/

Six Point Group Archive MSS 5 CMW/ 
WL Pamphlet Collection

Women's Forum/Women's Group on Public Welfare Archive MSS 5 WFM/

\section{Newspapers and periodicals}

The Blue Triangle Gazette

The Catholic Citizen

The Catholic Women's League Magazine

The Catholic Women's Outlook

Co-operative News

Daily Mail

Guardian

Home and Country

Home and Family

Manchester Guardian

Mothers in Council

Mothers' Union News

The Mothers' Union Journal

The Mothers' Union Journal (London Cover).

The Mothers' Union Workers' Paper

National Council of Women News

News For Citizens

The Sunday Pictorial

The Tablet

Time and Tide

The Times

The Townswoman

Woman

Women in Council

The Women's Leader

\section{Contemporary sources and pamphlets}

Abbott, E. and Bompass, K., The Woman Citizen and Social Security; A Criticism of the Proposals Made in the Beveridge Report as They Affect Women (1943).

Barclay, E. Noel, Marriage and Divorce (1936).

Beveridge, W., Social Insurance and Allied Services (London: HMSO, Cmd 6404, 1942).

Campbell, H. M., Maternal Mortality, Reports on Public Health and Medical Subjects \# 25 (London: HMSO, 1924).

Campbell, J., The Protection of Motherhood, Reports on Public Health and Medical Subjects \# 48 (London: HMSO, 1927).

Central Office of Information, Women in Britain Reference Pamphlet 67 (London: HMSO, 1964). 
Constitution of the National Women Citizens' Association (1918).

Cowlin, M. H., Women Police in War Time: What is the WAPC? (1939).

Design of Dwellings: Report of Central Housing Committee (London: HMSO, 1944).

Encyclical Letter from the Bishops, Resolutions and Reports of the Lambeth

Conference 1930 (1930).

Encyclical Letter from the Bishops, Resolutions and Reports of the Lambeth Conference 1948 (1948).

Equal Pay Campaign Committee, Equal Pay for Equal Work (1944).

Equal Pay Campaign Committee, Equal Pay for Equal Work: A Black Record

(London: EPCC, 1949).

Evans, D., The Case For Equal Pay (1948).

Evidence for the Central Housing Advisory Committee's Sub-Committee on the

Design of Dwellings (London: HMSO, 1946)

Evidence to the Royal Commission on Marriage and Divorce 1952 (London: HMSO, 1952).

Ferguson, S. and Fitzgerald, H., Studies in Social Services (London: HMSO, 1954). Hubback, E., Training For Citizenship (London: AEC, 1935).

- - The Making of Citizens (London: AEC, 1942).

Hubback, E. and Simon, E., Education For Citizenship (London: AEC, 1934).

Memorandum Submitted by the Mothers' Union to the Royal Commission on Marriage and Divorce, 1951-1955 (London: HMSO, 1955).

Ministry of Health, Final Report of the Departmental Committee on Maternal Mortality and Morbidity (London: HMSO, 1932).

Ministry of Health, Interim Report of the Departmental Committee on Maternal Mortality and Morbidity (London: HMSO, 1930).

Ministry of Health, Report on an Investigation into Maternal Mortality (London: HMSO, 1937).

The National Association of Women Civil Servants Newsletter (July 1948).

National Conference of Women, called by HM Government: Report of Proceedings, Tuesday 28 September 1943, Royal Albert Hall, London (1943).

The National Council of Women, The First Sixty Years 1895-1955 (London: NCW, 1955).

The National Council of Women: What Is It? (1929).

National Federation of Women's Institutes Annual Reports (1928-64).

National Federation of Women's Institutes Annual Conference Reports (1928-64).

National Federation of Women's Institutes Procedure at Meetings (1949).

National Federation of Women's Institutes, Public Questions Annual Record (London: NFWI, 1956).

National Federation of Women's Institutes, Town Children through Country Eyes:

A Survey on Evacuation (1940).

The National Insurance Act 1946 (London: HMSO, 1946).

National Union of Townswomen's Guilds Annual Reports (1928-64).

National Union of Townswomen's Guilds Handbooks (1928-64).

NCW Handbooks (1928-64). 
NCW Reports of Council Meetings and Conferences (1928-64).

Oral Evidence submitted to the Royal Commission on Population, 1944-1945

(London: HMSO, 1949).

Papers of the Royal Commission on Population (London: HMSO, 1949).

Pope Leo XIII, Rerum Novarum: The Condition of the Working Classes (Encyclical, 1891).

Pope Pius XI, Quadragesimo Anno: The Social Order - Its Reconstruction and Perfection (Encyclical, 1931).

Pope Pius XI, Casti Connubii: Encyclical Letter of His Holiness Pope Pius XI on Christian Marriage, December 1930 (London: Sheed \& Ward, 1933)

Report of the Royal Commission on Equal Pay (London: HMSO, 1946).

Report of the Royal Commission on Population (London: HMSO, 1949).

Report of the Royal Commission on Marriage and Divorce (London: HMSO, 1956)

Tate, M., Equal Work Deserves Equal Pay (n.d.).

Thomas, G., Women and Industry: An Inquiry into the Problem of Recruiting

Women to Industry Carried Out for the Ministry of Labour and National Service (1943)

Ward, D., The Christian Attitude towards Birth Control and Abortion (1937).

- Marriage and Divorce (n.d.).

Women's Group on Public Welfare, Our Towns: A Close Up (Oxford: WGPW, 1943). Women's Group on Public Welfare Report 1939-45 (1945).

Women's Housing and Planning Conference (1942).

Written Evidence Submitted to the Royal Commission on Population 1944-47 (London: HMSO, 1949).

\section{Articles and chapters}

Beaumont, C., 'Women and the Politics of Equality: The Irish Women's Movement, 1930-1943', in M. O'Dowd and M. Valiulis (eds), Women and Irish History (Dublin: Wolfhound Press, 1997).

— , 'Citizens not Feminists: The Boundary Negotiated between Citizenship and Feminism by Mainstream Women's Organisations in England, 1928-1939', Women's History Review, 9:2 (2000).

—_ 'The Women's Movement, Politics and Citizenship, 1918-1950', in I. Zweiniger-Bargielowska (ed.), Women in Twentieth Century Britain (Harlow: Pearson Education, 2001).

— ' 'Moral Dilemmas and Women's Rights: The attitude of the Mothers' Union and Catholic Women's League to divorce, birth control and abortion in England 1928-1939', Women's History Review, 16:4 (2007).

—_, 'Housewives, Workers and Citizens: Voluntary Women's Organisations and the Campaign for Women's Rights in England and Wales during the Post-war Period', in N. Crowson, M. Hilton and J. Mckay (eds), NGOs in Contemporary Britain: Non-State Actors in Society and Politics since 1945 (Basingstoke: Palgrave Macmillan, 2009). 
, 'Where to Park the Pram? Voluntary Women's Organisations, Citizenship and the Campaign for Better Housing in England, 1928-1945', Women's History Review, 22:1 (2013).

Beinart, J., 'Obstetric Analgesia and the Control of Childbirth in TwentiethCentury Britain', in J. Garcia, R. Kilpatrick and M. Richards (eds), The Politics of Maternity Care: Services for Childbearing Women in Twentieth-Century Britain (London: Clarendon Paperbacks, 1990).

Birmingham Feminist History Group, 'Feminism as Femininity in the Nineteenfifties?', Feminist Review, 3 (1979).

Black, A. and Brooke, S., 'The Labour Party, Women and the Problem of Gender, 1951-1966', Journal of British Studies, 36 (1997).

Blackford, C., 'Wives and Citizens and Watchdogs of Equality: Post-war British Feminism', in J. Fyrth (ed.), Labour's Promised Land? Culture and Society in Labour Britain 1945-51 (London: Lawrence and Wishhart, 1995).

Brooke, S., “A New World for Women?” Abortion Law Reform in Britain during the 1930s", American Historical Review, 106 (2001).

— , 'The Sphere of Sexual Politics: The Abortion Law Reform Association, 1930 s

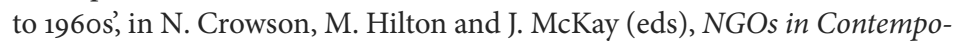
rary Society: Non-State Actors in Society and Politics since 1954 (Basingstoke: Palgrave Macmillan, 2009).

Canning, K. and Rose, S. O., 'Gender, Citizenship and Subjectivity: Some Historical and Theoretical Considerations', in K. Canning and S. O. Rose (eds), Gender, Citizenship and Subjectivities (Oxford: Blackwell, 2002).

Clapson, M., 'Working-Class Women's Experiences of Moving to New Housing Estates in England since 1919', Twentieth Century British History, 10:3 (1999).

Cohen, D., 'Private Lives in Public Spaces: Marie Stopes, the Mothers Clinics and the Practice of Contraception', History Workshop Journal, 35 (1993).

Dahlerup, D., 'Three Waves of Feminism in Denmark', in G. Griffin and R. Braidotti (eds), Thinking Differently: A Reader in European Women's Studies (London: Zed Books, 2002).

Darling, E., "Enriching and Enlarging the Whole Sphere of Human Activities": The Work of the Voluntary Housing Sector in Housing Reform in Inter-war Britain', in C. Lawrence and A. Mayer (eds), Regenerating England: Science, Medicine and Culture in Inter-War Britain (Atlanta: Editions Rodopi B. V., 2000).

_- "A citizen as well as a housewife": New Spaces of Domesticity in 1930s London', in H. Heynen and G. Baydar (eds), Negotiating Domesticity: Spatial Productions of Gender in Modern Architecture (London: Routledge, 2005).

Davies, R., 'Marking the 5oth Anniversary of the Platt Report: From Exclusion, to Toleration and Parental Participation in the Care of the Hospitalised Child, Journal of Child Health Care, 14:1 (2010).

Davin, A., 'Imperialism and Motherhood', History Workshop Journal, 5 (1978).

Evans, T., 'Stopping the Poor Getting Poorer: The Establishment and Professionalization of Poverty NGOs, 1945-95', in N. Crowson, M. Hilton and J. McKay 
(eds), NGOs in Contemporary Britain: Non-State Actors in Society and Politics since 1945 (Basingstoke: Palgrave Macmillan, 2009).

Finch, J. and Summerfield, P. 'Social Reconstruction and the Emergence of Companionate Marriage, 1945-59', in D. Clark (ed.), Marriage, Domestic Life and Social Change: Writings for Jacqueline Burgoyne (1944-88) (London: Routledge, 1991).

Giles, J., "'Playing Hard to Get”: Working Class Women, Sexuality and Respectability in Britain, 1918-40', Women's History Review, 1:2 (1992).

—_ 'A Home of One's Own: Women and Domesticity in England, 1918-1950', Women's Studies International Forum, 16:3 (1993).

Gittins, D., 'Married Life and Birth Control between the Wars', Oral History 3:1 (1975).

Hall, C., 'The History of the Housewife', in E. Malos (ed.), The Politics of Housework (London: Allison and Busby, 1980).

Harris, J., 'Political Thought and the Welfare State, 1870-1940', Past and Present, 135 (1992).

Harrison, B., 'For Church, Queen and Family: The Girls' Friendly Society 1874-1920', Past and Present, 61 (1973).

—, 'Women in a Men's House: The Women MPs, 1919-1945', The Historical Journal, 29:3 (1986).

Hinton, J., 'Women and the Labour Vote, 1945-50' Labour History Review 57:3 (1992).

—, 'Militant Housewives: The British Housewives' League and the Attlee Government', History Workshop Journal, 38 (1994).

Hufton, O., 'What is Women's History', History Today, 35 (1985).

Hunt, K., 'Negotiating the Boundaries of the Domestic: British Socialist Women and the Politics of Consumption', Women's History Review, 9:2 (2000).

Hunt, K., 'Women as Citizens: Changing the Polity', in D. Simonton (ed.), The Routledge History of Women in Europe Since 1700 (London: Routledge, 2006).

Innes, S., 'Constructing Women's Citizenship in the Inter-war Period: The Edinburgh Women's Citizens' Association', Women's History Review, 13:4 (2000).

Koven, S. and Michel, S., 'Womanly Duties: Maternalist Politics and the Origins of Welfare States in France, Germany, Great Britain, and the United States', American Historical Review, 95:11 (1990).

Land, H., 'The Family Wage', Feminist Review, 6 (1980).

__ 'Eleanor Rathbone and the Economy of the Family', in H. Smith (ed.), British Feminism in the Twentieth Century (London: Edward Elgar, 1990).

— ' 'Motherhood, Race and the State in the Twentieth Century: An Introduction', Gender and History 4:3 (1992).

Langhamer, C., 'The Meanings of Home in Postwar Britain' Journal of Contemporary History, 40:2 (2005).

—, 'Adultery in Post-War England', History Workshop Journal, 62 (2006).

Levine, P., "Walking the Streets in a Way No Decent Woman Should": Women Police in World War I', Journal of Modern History, 66:1 (1994). 
Lewis, J., 'The Ideology and Politics of Birth Control in Inter-War England', Women's Studies International Quarterly, 2 (1979).

— - 'In Search of a Real Equality: Women between the Wars', in F. Gloversmith (ed.), Class, Culture and Social Change: A New View of the 1930s (Brighton: Harvester Press, 1980).

__ 'Dealing with Dependency: State Practices and Social Realities, 1870-1945', in J. Lewis (ed.), Women's Welfare/Women's Rights (London: Croom Helm, 1983).

_- 'Mydral, Klein: Women's Two Roles and Post-war Feminism 1945-1960', in H. Smith (ed.), British Feminism in the Twentieth Century (London: Edward Elgar, 1990).

_- 'Mothers and Maternity Policies in the Twentieth Century', in J. Garcia, R. Kilpatrick and M. Richards (eds), The Politics of Maternity Care: Services for Childbearing Women in Twentieth-Century Britain (London: Clarendon Paperbacks, 1990).

— ' 'Models of Equality for Women: The Case of State Support for Children in Twentieth-Century Britain', in G. Bock and P. Thane (eds), Maternity and Gender Policies: Women and the Rise of European Welfare States, 1880s to 1950s (London: Routledge, 1991).

Lister, R., 'Citizenship: towards a Feminist Synthesis', Feminist Review, 57 (1997).

McCarthy, H., 'Parties, Voluntary Associations and Democratic Politics in Interwar Britain', Historical Journal, 50 (2007).

__ 'Service Clubs, Citizenship and Equality: Gender Relations and Middle-class Associations in Britain between the Wars', Historical Review, 81 (2008).

McCarthy, H. and Thane, P., 'The Politics of Association in Industrial Society', Twentieth Century British History, 22 (2011).

Macnicol, J., 'The Effect of the Evacuation of Schoolchildren on Official Attitudes to State Intervention', in H. Smith (ed.), War and Social Change: British Society in the Second World War (Manchester: Manchester University Press, 1986).

Marks, L., 'Mothers, Babies and Hospitals: “The London" and Provision of Maternity Care in East London, 1870-1939', in V. Fildes, L. Marks and H. Marland (eds), Women and Children First: International Maternal and Infant Welfare, 1870-1945 (London: Routledge, 1992).

Mason, F. M., 'The Newer Eve: The Catholic Women's Suffrage Society in England, 1911-1923, Catholic History Review, 4 (1986).

Meehan, E., 'British Feminism from the 196os to the 1980s', in H. Smith (ed.), British Feminism in the Twentieth Century (London: Edward Elgar, 1990).

Meyerowitz, J., 'Beyond the Feminine Mystique: A Reassessment of Post-war Mass Culture, 1946-1958', The Journal of American History, 79:4 (1993).

Morgan, M., 'Jam Making, Cuthbert Rabbit and Cakes: Redefining Domestic Labour in the Women's Institutes, 1915-60', in Rural History, 7:2 (1996).

Offen, K., 'Defining Feminism: A Comparative Historical Approach', Signs, 14 (1988-89). 
Pateman, C., 'The Patriarchal Welfare State', in A. Gutmann (ed.), Democracy and the Welfare State (Princeton, Princeton University Press, 1988).

—, 'Equality, Difference, Subordination: The Politics of Motherhood and Women's Citizenship', in G. Bock and S. James (eds), Beyond Equality and Difference (London: Routledge, 1992).

Pedersen, S., 'The Failure of Feminism in the Making of the British Welfare State', Radical History Review, 43 (1989).

__, 'Gender, Welfare, and Citizenship in Britain during the Great War', American Historical Review, 95:4 (1990).

Peretz, E., 'A Maternity Service for England and Wales: Local Authority Maternity Care in the Inter-war period in Oxfordshire and Tottenham', in J. Garcia, R. Kilpatrick and M. Richards (eds), The Politics of Maternity Care: Services for Childbearing Women in Twentieth-Century Britain (London: Clarendon Paperbacks, 1990).

—, 'The Costs of Modern Motherhood to Low Income Families in Inter-war Britain', in V. Fildes, L. Marks and H. Marland (eds), Women and Children First: International Maternal and Infant Welfare 1870-1945 (London: Routledge, 1992).

Perriton, L., 'Forgotten Feminists: The Federation of British Professional and Business Women, 1933-1969', Women's History Review, 16:1 (2007).

Phillips, A., 'Citizenship and Feminist Theory', in G. Andrews (ed.), Citizenship (London: Lawrence and Wishart, 1991).

—_, 'Must Feminists Give Up on Liberal Democracy', in D. Held (ed.), Prospects for Democracy: North, South, East and West (Cambridge, Cambridge University Press, 1993).

Potter, A., 'The Equal Pay Committee: A Case Study of a Pressure Group', Political Studies, 5 (1957).

Prochaska, F., 'A Mothers' Country: Mothers' Meetings and Family Welfare in Britain, 1850-1950', History, The Journal of the Historical Association, 74 (1989).

Pugh, M., 'Domesticity and the Decline of Feminism, 1930-1950', in Smith (ed.), British Feminism in the Twentieth Century (London: Edward Elgar, 1990).

Rathbone, E., 'Changes in Public Life', in R. Strachey (ed.), Our Freedom and Its Results (London: Hogarth Press, 1936).

Ravetz, A., 'A View from the Interior', in J. Attfield and P. Kirkham (eds), A View From the Interior: Feminism, Women and Design (London: The Women's Press, 1989).

—_, 'Housing the People' in J. Fyrth (ed.), Labour's Promised Land? Culture and Society in Labour Britain 1945-51 (London: Lawrence and Wishhart, 1995).

Riley, D., 'War in the Nursery', Feminist Review, 2 (1979).

_ - 'Some Peculiarities of Social Policy Concerning Women in Wartime and Post-War Britain', in M. R. Higonnet, J. Jenson, S. Michel and M. C. Weitz (eds), Behind The Lines: Gender and the Two World Wars (New Haven: Yale University Press, 1987).

Robinson, S., 'Maintaining the Independence of the Midwifery Profession: A

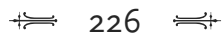


Continuing Struggle, in J. Garcia, R. Kilpatrick and M. Richards (eds), The Politics of Maternity Care: Services for Childbearing Women in TwentiethCentury Britain (London: Clarendon Paperbacks, 1990).

Rowan, C., 'Women in the Labour Party, 1906-1920', Feminist Review, 12 (1982). Scott, G., “A Trade Union for Married Women”: The Women's Co-operative Guild 1914-1920', in S. Oldfield (ed.), The Working Day World: Women's Lives and Culture(s) in Britain 1914-1945 (London: Taylor and Francis, 1994).

__, "Workshops Fit for Homeworkers": The Women's Co-operative Guild and Housing Reform in Mid-twentieth Century Britain', in E. Darling and L. Whitworth (eds), Women and the Making of Built Space in England 1870-1950 (Aldershot: Ashgate, 2007).

Smart, C., 'Disruptive Bodies and Unruly Sex', in C. Smart (ed.), Regulating Womanhood (London: Routledge, 1992).

Smith, H., 'The Problem of "Equal Pay for Equal Work" in Great Britain during World War II', Journal of Modern History, 53 (1981).

—, 'The Effect of the War on the Status of Women', in H. Smith (ed.), War and Social Change: British Society in the Second World War (Manchester: Manchester University Press, 1986).

—, 'British Feminism in the 1920s', in H. Smith (ed.), British Feminism in the Twentieth Century (London: Edward Elgar, 1990).

_ - 'The Politics of Conservative Reform: The Equal Pay for Equal Work Issue, 1945-1955', The Historical Journal, 35:2 (1992).

—, 'British Feminism and the Equal Pay Issue in the 1930s', Women's History Review, 5:1 (1996).

Smith Wilson, D., 'A New Look at the Affluent Worker: The Good Working Mother in Post-war Britain', Twentieth Century British History, 17:2 (2006).

Summerfield, P., 'Women, War and Social Change: Women in Britain in World War II', in A. Marwick (ed.), Total War and Social Change (Basingstoke: Macmillan, 1988).

__ 'Women in Britain since 1945: Companionate Marriage and Double Burden', in J. Obelkevich and P. Catterall (eds), Understanding Post-war British Society (London: Routledge, 1994).

Thane, P., 'Women of the British Labour Party and Feminism, 1906-45', in H. Smith (ed.), British Feminism in the Twentieth Century (London: Edward Elgar, 1990).

__ 'Towards Equal Opportunities? Women in Britain since 1945', in T. Gourvish and A. O’Day (eds), Britain Since 1945 (Basingstoke: Macmillan, 1991).

— , 'Visions of Gender in the Making of the British Welfare State: The Case of Women in the British Labour Party and Social Policy, 1906-1945', in G. Bock and P. Thane (eds), Maternity and Gender Policies: Women and the Rise of European Welfare States, 1880 s to 1950s (London: Routledge, 1991).

_- 'Women in the British Labour Party and the Construction of State Welfare, 1906-1936', in S. Koven and S. Michel (eds), Mothers of a New World: Maternalist Politics and the Origins of Welfare States (London: Routledge, 1993).

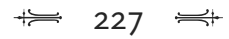


_- 'Women, Liberalism and Citizenship', in E. Biagini (ed.), Citizenship and Community: Liberals, Radicals and Collective Identities in the British Isles, 1865-1931 (Cambridge: Cambridge University Press, 1996).

—_, 'Family Life and "Normality" in Post-War British Culture', in R. Bessel and D. Schumann (eds), Life After Death: Approaches to a Cultural and Social History of Europe during the 1940s and 1950s (Cambridge: Cambridge University Press, 2003).

__ 'Women and Political Participation in England, 1918-1970', in E. Breitenbach and P. Thane (eds), Women and Citizenship in Britain and Ireland in the Twentieth Century: What Difference Did the Vote Make?(London: Continuum, 2010).

Turner, B. S., 'Outline of a Theory of Citizenship', Sociology, 24:2 (1990).

Walby, S., 'Is Citizenship Gendered?', Sociology, 28:2 (1994).

Welshman, J., 'Evacuation, Hygiene and Social Policy: The Our Towns Report of 1943', Historical Journal, 42 (1999).

Woodesen, A., 'The First Women Police: A Force for Equality or Infringement?', Women's History Review, 2:2 (1993).

Woollacott, A., "Khaki Fever" and Its Control: Gender, Class, Age and Sexual Morality on the British Homefront in the First World War', Journal of Contemporary History, 29 (1994).

Wright, V., "Education for Active Citizenship": Women's Organisations in Interwar Scotland', History of Education, 38:3 (2009).

Yuval-Davis, N., 'Women, Citizenship and Difference', Feminist Review, 57 (1997).

Zweiniger-Bargielowska, I., 'Bread Rationing in Britain, July 1946-July 1948', Twentieth Century British History, 4:1 (1993).

__ ' 'Rationing, Austerity and the Conservative Party Recovery after 1945', Historical Journal, 37:1 (1994).

—_ 'Explaining the Gender Gap: The Conservative Party and the Women's Vote', in M. Francis and I. Zweiniger-Bargielowska (eds), The Conservatives and British Society, 1880-1990 (Cardiff: University of Wales Press, 1996).

—, 'Housewifery', in I. Zweiniger-Bargielowska (ed.), Women in Twentieth Century Britain (London: Palgrave Macmillan, 2001)

\section{Books}

Adam, P. (ed.), Women in Council: The Jubilee Book of the National Council of Women of Great Britain (Oxford: Oxford University Press, 1945).

Alberti, J., Beyond Suffrage: Feminists in War and Peace, 1914-28 (Basingstoke: Palgrave Macmillan, 1989).

Alfred, M., During Six Reigns: Landmarks in the History of the National Council of Women of Great Britain (London: NCW, 1955).

Andrews, M., The Acceptable Face of Feminism: The Women's Movement as a Social Movement (London: Lawrence and Wishart, 1997).

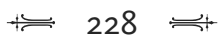


Banks, O., Faces of Feminism: A Study of Feminism as a Social Movement (Oxford: Blackwell, 1981).

Beddoe, D., Back to Home and Duty: Women Between the Wars, 1918-1939 (London: Pandora, 1989).

Beveridge, W. and Wells, A. F., The Evidence for Voluntary Action (London: Allen and Unwin, 1949).

Bourke, J., Working-Class Cultures in Britain 1890-1960 (London: Routledge, 1993).

Bowlby, J., Childcare and the Growth of Love (London: Penguin, 1953).

Braithwaite, C., The Voluntary Citizen: An Enquiry into the Place of Philanthropy in the Community (London: Methuen, 1938).

Braybon, G. and Summerfield, P., Out of the Cage: Women's Experiences in Two World Wars (London: Pandora, 1987).

Bristow, E., Vice and Vigilance: Purity Movements in Britain since 1700 (Dublin: Gill and Macmillan, 1977).

Brookes, B., Abortion in England 1900-1967 (London: Croom Helm, 1988).

Bruley, S., Women in Britain Since 1900 (Basingstoke: MacMillan, 1999).

Burnett, J., A Social History of Housing 1815-1985 (London: Methuen, 1986).

Caine, B., English Feminism 1780-1980 (Oxford: Oxford University Press, 1997).

Campbell, B., The Iron Ladies: Why Do Women Vote Tory? (London: Virago, 1987).

Carrier, J., The Campaign for the Employment of Women As Police Officers (Aldershot: Avebury, 1988).

Cook, H., The Long Sexual Revolution: English Women, Sex and Contraception 1800-1975 (Oxford: Oxford University Press, 2004).

Conekin, B., Mort, F. and Waters, C. (eds), Moments of Modernity: Reconstructing Britain 1945-1964 (London: Rivers Oram Press, 1999).

Courtney, J., Countrywomen in Council (Oxford: Oxford University Press, 1933).

Cowman, K., Women in British Politics, c.1689-1979 (Basingstoke: Palgrave Macmillan, 2010).

Davies Llewellyn, M. (ed.), Maternity: Letters from Working Women (London: Bell, 1915).

Dyhouse, C., Feminism and the Family in England, 1880-1930 (Oxford: Oxford University Press, 1989).

Ferguson, M., Forever Feminine: Women's Magazines and the Cult of Femininity (London: Heinmann, 1983).

Fisher, K., Birth Control, Sex and Marriage in Britain, 1918-1960 (Oxford: Oxford University Press, 2006).

Gibson, L., Beyond Jerusalem: Music in the Women's Institute, 1919-1969 (London, Ashgate, 2008).

Gittens, J., Fair Sex: Family Size and Structure, 1900-39 (London: Hutchinson, 1982).

Glick, D., The National Council of Women of Great Britain: The First One Hundred Years (London: NCW, 1995).

Glucksman, M., Women Assemble: Women Workers in the New Industries of Interwar Britain (London: Routledge, 1989). 
Goldsmith, M., Women and the Future (London: Lindsay Drummond Ltd, 1946). Goodenough, S., Jam and Jerusalem (Glasgow: Collins, 1977).

Gordon, P. and Dougan, D., Dictionary of British Women's Organisations 1825-1960 (London: Woburn Press, 2001).

Griffith, E. F., Modern Marriage and Birth Control (London: Gollancz, 1935).

Hall, L. A., Sex, Gender and Social Change in Britain since 1880 (Basingstoke: Macmillan, 2000).

Hall, R., Marie Stopes: A Biography (London: Virago Ltd., 1978).

—, Dear Dr. Stopes: Sex in the 1920s (London: Deutsch, 1978).

Harrison, B., Prudent Revolutionaries: Portraits of British Feminists between the Wars (Oxford: Oxford University Press, 1987).

Herbert, A. P., Holy Deadlock (London: Methuen and Co., 1934).

- The Ayes Have It: The Story of the Marriage Bill (London: Methuen and Co., 1937).

Hilton, M., Consumerism in Twentieth Century Britain (Cambridge: Cambridge University Press, 2003).

Hinton, J., Women, Social Leadership, and the Second World War: Continuities of Class (Oxford: Oxford University Press, 2002).

Hollis, P., Women in Public Life: The Women's Movement 1850-19oo, Documents of the Victorian Women's Movement (London: George Allen and Unwin, 1979).

- Ladies Elect: Women in English Local Government 1865-1914 (Oxford: Oxford University Press, 1987).

The Hutchinson Woman's Who's Who (London: Hutchinson, 1934).

Jackson, L., Women Police: Gender, Welfare and Surveillance in the Twentieth Century (Manchester: Manchester University Press, 2006).

Jenkins, I., The History of the Women's Institute Movement of England and Wales (Oxford: Oxford University Press, 1953).

Jephcott, P., Rising Twenty: Notes on Some Ordinary Girls (London: Faber and Faber, 1948).

Kitchen, P., For Home and Country: War, Peace and Rural Life as Seen through the Pages of the Women's Institutes' Magazine, 1919-1959 (London: Ebury, 1990).

Law, C., Suffrage and Power: The Women's Movement, 1918-1928 (London: I. B. Tauris, 1997).

Lewis, J., Women in England 1870-1950: Sexual Divisions and Social Change (Brighton: Wheatsheaf, 1984).

- Women in Britain Since 1945: women, family, work and the state in the post-war years (Oxford: Blackwell, 1992).

- (ed.), Women's Welfare/Women's Rights (London: Croom Helm, 1983).

- (ed.), Labour and Love: Women's Experience of Home and Family 1850-1940 (Oxford: Oxford University Press, 1986).

Lister, R., Citizenship: Feminist Perspectives (Basingstoke: Palgrave, 1997).

Loudon, I., Death in Childbirth: An International Study of Maternal Care and Maternal Mortality, 1800-1950 (Oxford: Clarendon Press, 1992).

Macnicol, J., The Movement for Family Allowances (London: Heinemann, 1980).

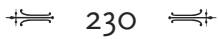


Marshall, T. H., Citizenship and Social Class (Cambridge: Cambridge University Press, 1950).

Merz, C., After the Vote: The Story of the National Union of Townswomen's Guilds in the Year of Its Diamond Jubilee 1929-1989 (Norwich: National Union of Townswomen's Guilds, 1988).

Mowat, C., Britain Between the Wars, 1918-1940 (London: Methuen, 1955).

Moyse, C., A History of the Mothers' Union: Women, Anglicanism and Globalisation (London: The Boydell Press, 2009).

Myrdal, A. and Klein, V., Women's Two Roles: Home and Work (London: Routledge and Kegan Paul Ltd, 1956).

National Federation of Women's Institutes, Keeping Ourselves Informed: Our Concerns, Our Resolutions, Our Actions (London: NFWI, 1981).

Noakes, L., War and the British: Gender, Memory and National Identity 1939-1991 (London: I. B. Tauris, 1998).

Offen, K., European Feminisms, 1700-1950 (Stanford: Stanford University Press, 2000).

Parker, O., For The Family's Sake: A History of the Mothers' Union 1876-1976 (Folkstone: Bailey and Swinfen, 1975).

Pateman, C., The Disorder of Women (Cambridge: Cambridge University Press, 1989).

Phillips, R., Putting Asunder: A History of Divorce in Western Society (Cambridge: Cambridge University Press, 1988).

Pugh, M., Women's Suffrage in Britain 1867-1928 (London: Historical Association, 1980).

- The Tories and the People (Oxford: Oxford University Press, 1985).

—, Women and the Women's Movement in Britain, 1914-1999 (2nd ed; Basingstoke: MacMillan, 2000).

Rathbone, E., The Disinherited Family (London: E. Arnold and Co., 1924).

Roberts, E., A Woman's Place: An Oral History of Working-Class Women, 189o-1940 (Oxford: Blackwell, 1984).

Robertson Scott, J. W., The Story of the Women's Institute Movement (Kingham: Village Press, 1925).

Rose, S. O., Which People's War? National Identity and Citizenship in Britain 1939-45 (Oxford: Oxford University Press, 2003).

Ryan, M., Yesterday Recalled: A Jubilee History of the Catholic Women's League 1906-1981 (London: Catholic Women's League, 1981).

Scott, G., Feminism, Femininity and the Politics of Working Women: The Women's Co-operative Guild, 1880s to the Second World War (London: University College London Press, 1998).

Segal, L., Straight Sex: The Politics of Pleasure (London: Virago, 1994).

Sheridan, D. (ed.), Wartime Women: An Anthology of Women's Wartime Writing for Mass Observation 1937-45 (London: Phoenix, 1990).

Soloway, R., Birth Control and the Population Question in England 1877-1930 (Chapel Hill: University of North Carolina, 1982). 
Spring Rice, M., Working Class Wives (London: Penguin, 1939).

Stone, L., The Road to Divorce: England 1530-1987 (Oxford: Oxford University Press, 1990).

Stott, M., Organisation Woman: The Story of The National Union of Townswomen's Guilds (London: Heinemann, 1978).

Strachey, R. (ed.), Our Freedom and Its Results (London: Hogarth, 1936).

Summerfield, P., Women Workers in the Second World War: Production and Patriarchy in Conflict (London: Routledge, 1984).

Sutton, M., 'We Didn't Know Aught': A Study of Sexuality, Superstition and Death in Women's Lives in Lincolnshire during the 1930s, '40s and '50s (Stamford: Paul Watkins, 1992).

Tancred, E., Women Police 1914-1950 (London: NCW, 1950).

Vincent, D., Poor Citizens (London: Longman, 1991).

Weeks, J., Sex, Politics and Society: the Regulation of Sexuality since 1800 (London: Longman, 1981).

Weinberger, B., The Best Police in the World: An Oral History of English Policing (Aldershot: Scolar Press, 1995).

White, C. L., Women's Magazines, 1693-1968 (London: Joseph, 1970).

Wilson, E., Only Halfway to Paradise: Women in Post-War Britain: 1945-1968 (London: Tavistock, 1980).

Winnicott, D., Getting to Know Your Baby (London: Heinemann, 1945).

Zweiniger-Bargielowska, I., Austerity in Britain: Rationing, Controls and Consumption 1939-1955 (Oxford: Oxford University Press, 2000).

\section{Unpublished sources}

Blackford, C., 'Ideas, structures and practices of feminism, 1939-1964' (Ph.D. dissertation, University of East London, 1996).

Clements, S., 'Feminism, citizenship and social activity: the role and importance of local women's organisations, Nottingham 1918-1969' (Ph.D. dissertation, University of Nottingham, 2008).

Davidson, R., 'Citizens at last: women's political culture and civil society, Croydon and East Surrey, 1914-39' (Ph.D. dissertation, Royal Holloway, University of London, 2010).

Field, J. and Weller, P., 'The association for education in citizenship, 1935-1955', unpublished paper presented to 'The Left and Citizenship in the 1940s and After', a workshop held at the University of Warwick, 7 November 1991.

Freeguard, J., 'It's time for women of the 1950 s to stand up and be counted' (Ph.D. dissertation, University of Sussex, 2004).

Kent, J., 'The attitudes of the British churches to citizenship and national identity 1920-1960, with special reference to the work of William Temple', presented to 'The Right to Belong: Citizenship and National Identity', a conference held at the University of London, 7 May 1994. 
Morgan, M., 'The acceptable face of feminism: the Women's Institute movement 1915-1960' (Ph.D. dissertation, University of Sussex, 1992).

Noble, V., 'A mission for women: a reflection on the history of women's organisations in the Catholic Church and their relevance within the contemporary Church' (Diploma dissertation, University of London, 1991).

North, D. L., 'Middle class suburban lifestyles and culture in England 1919-1939' (Ph.D. dissertation, Oxford, 1989).

Richie, R., 'The housewife and the modern: the home and appearance in women's magazines, 1954-1969' (Ph.D. dissertation, University of Manchester, 2010). 